\title{
2006 Update for Implementing Best Available Technology Per DOE Order 5400.5
}

Michael G. Lewis

September 2007

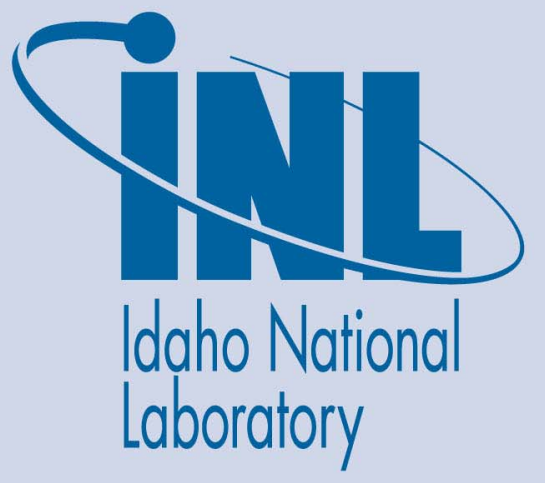

The INL is a U.S. Department of Energy National Laboratory operated by Battelle Energy Alliance 
INL/EXT-07-12945

\section{Update for Implementing Best Available Technology Per DOE Order $\mathbf{5 4 0 0 . 5}$}

Michael G. Lewis

September 2007

Idaho National Laboratory

Idaho Falls, Idaho 83415

Prepared for the

U.S. Department of Energy

Office of Nuclear Energy

Under DOE Idaho Operations Office

Contract DE-AC07-05ID14517 


\begin{abstract}
In accordance with Contract Data Requirements List F.19, this report addresses the Best Available Technology requirements per Department of Energy (DOE) Order 5400.5, "Radiation Protection of the Public and the Environment," as they apply to radiological discharges to the soil for Calendar Year 2006. The report includes review of discharges for both, Battelle Energy Alliance, LLC and CH2M-WG Idaho, LLC.

The Best Available Technology selection process is applicable to wastewater discharges containing process derived radionuclides to surface waters, sanitary sewerages greater than five times the Derived Concentration Guideline (found in DOE Order 5400.5), and to the soil. Wastewater at the Idaho National Laboratory Site is not discharged to surface water (Big Lost River and Birch Creek) nor is it discharged to sanitary sewerages at activity levels greater than five times a Derived Concentration Guideline. Therefore, this report focuses on radiological discharges to the soil.
\end{abstract}





\section{CONTENTS}

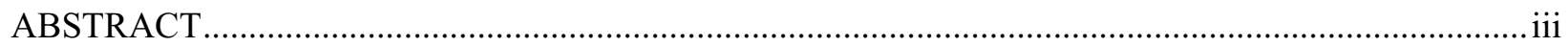

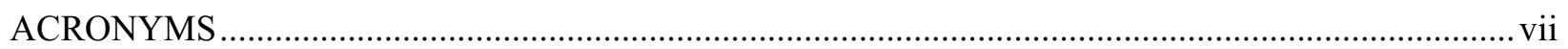

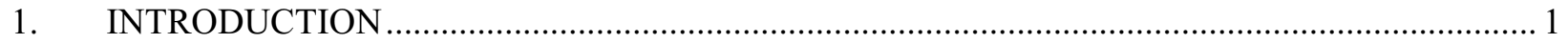

2. COMPLIANCE WITH BEST AVAILABLE TECHNOLOGY REQUIREMENTS ....................... 2

3. CALENDAR YEAR 2006 WASTEWATER DISCHARGES TO THE SOIL ............................... 3

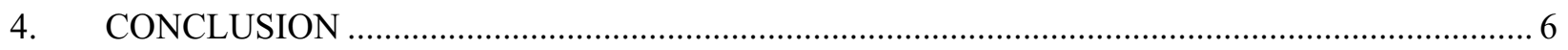

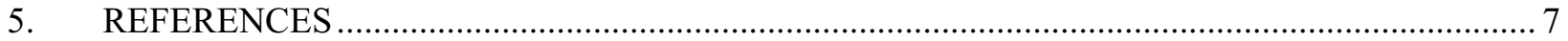

\section{TABLE}

Table 1. Frequency of sampling and analyses performed at each WLAF.............................. 



\section{ACRONYMS}

BAT best available technology

BEA Battelle Energy Alliance, LLC

CWI CH2M-WG Idaho, LLC

CWP Cold Waste Pond

DCG Derived Concentration Guide

DOE Department of Energy

DOE-ID Department of Energy Idaho Operations Office

EDF Engineering Design File

EDW Environmental Data Warehouse

EMIS Environmental Information System

EMPP Environmental Monitoring Program Plan

ICS interim control strategy

INL Idaho National Laboratory

INTEC Idaho Nuclear Technology and Engineering Center

IWTS Integrated Waste Tracking System

MCL maximum contaminant level

MFC Materials and Fuels Complex

MDA minimum detectable activity

$\mathrm{pCi} / \mathrm{L} \quad$ picocuries per liter

PLN plan

RTC Reactor Technology Complex

STF $\quad$ Sewage Treatment Facility

TAN Test Area North

TSF Technical Support Facility

WDDF Waste Determination and Disposition Form

WGS Waste Generator Services

WLAF wastewater land application facility 


\section{Update for Implementing Best Available Technology per DOE Order $\mathbf{5 4 0 0 . 5}$}

\section{INTRODUCTION}

In accordance with Contract Data Requirements List F.19, this report addresses the Best Available Technology (BAT) requirements per Department of Energy (DOE) Order 5400.5, "Radiation Protection of the Public and the Environment," and radiological discharges to the soil for Calendar Year 2006. The report includes review of discharges for both, Battelle Energy Alliance, LLC (BEA) and CH2M-WG Idaho, LLC (CWI).

The best available technology selection process is conducted according to DOE Order 5400.5, Chapter II, Section 3, "Management and Control of Radioactive Materials in Liquid Discharges and Phaseout of Soil Columns," and DOE guidance. " Typically, selection of BAT for a specific application is made from among candidate alternative treatment technologies. Those alternative treatment technologies are identified by an evaluation process according to DOE Order 5400.5, Chapter II, Section 3.a.(1)(a). The evaluation process includes factors related to technology, economics, and public policy considerations.

The BAT selection process is applicable to wastewater discharges to surface waters [DOE Order 5400.5, Chapter II, Section 3.a.(1)] that contain radioactivity levels above DOE Order 5400.5 Derived Concentration Guidelines (DCGs) or discharges to sanitary sewerages greater than five times the DCGs. During Calendar Year 2006, wastewater at the Idaho National Laboratory (INL) Site was not discharged to the Big Lost River, Little Lost River, or Birch Creek and there were no discharges to sanitary sewerages greater than five times the DCGs.

The BAT selection process is also applicable to liquid waste streams that will continue to be discharged to soil columns for indefinite periods and that contain process-derived radionuclides [DOE Order 5400.5, Chapter II, Section 3.b.(1)]. DOE Headquarters provided additional guidance ${ }^{\mathrm{a}}$ (ref. Section 2) for determining what is considered a discharge to a soil column. This guidance, as well as DOE Order 5400.5 requirements were incorporated into the BEA and CWI plans PLN-8104 "Management Plan and Implementation of Best Available Technology per DOE Order 5400.5 for Disposal of Wastewater" and PLN-932 "Management Plan and Implementation of Best Available Technology per DOE Order 5400.5 for Disposal of Wastewater", respectively. Following these plans insures compliance with DOE Order 5400.5 and DOE Headquarters guidance.

a.. James R. Cooper, DOE-ID, e-mail to Brett R. Bowhan, R. M. Kauffman, etc., "Perc Pond Update,” February 5, 2001, 10:38 a.m., CCN 35553. 


\section{COMPLIANCE WITH BEST AVAILABLE TECHNOLOGY REQUIREMENTS}

The plans (PLN-8104 and PLN-932) are self-implementing screening tools that establish radiological release levels for disposal of purged well water to the ground surface, and other wastewaters to wastewater land application facilities or directly to the ground surface. The plans require that wastewater containing radiological contaminants must be evaluated to ensure compliance with DOE Order 5400.5. The BAT selection process, as required by DOE Order 5400.5, applies to "wastewater that will continue to be discharged to soil columns for indefinite periods and that contain process-derived radionuclides."

For the purposes of these screening tools, if wastewater is below current drinking water maximum contaminant levels (MCLs) for radionuclides, then the goals of the BAT selection process have been met and the wastewater is considered "clean water" (from a radiological standpoint). Therefore, discharges of these wastewaters to the ground surface do not constitute discharge to a soil column. Adherence to the recommendations in the plans is appropriate documentation of the BAT selection process and compliance with DOE Order 5400.5. Plans PLN-8104 and PLN-932 describe how to determine if radionuclide levels in wastewater are at or below the MCLs

For wastewater with radioactivity above MCLs, but below one DCG, the wastewater is considered acceptable for discharge to the soil provided the BAT selection process has been completed. Typically, selection of the BAT for a specific application will be made from among candidate alternative treatment technologies, which are identified by an evaluation process in accordance with DOE Order 5400.5, Chapter II, Section 3.a.(1)(a) that includes factors related to technology, economics, and public policy considerations. The BAT plan must be submitted to the DOE Field Office Manager for approval. Annually, the BAT plan must be revised and resubmitted to the DOE Field Office Manager for approval.

Wastewater with radiological activity levels above DCGs may not be disposed of to the soil. Alternative disposal methods must be used for these wastewaters. 


\section{CALENDAR YEAR 2006 WASTEWATER DISCHARGES TO THE SOIL}

Although plans PLN-8104 and PLN-932 are self-implementing for releases below MCLs, users may seek assistance in determining wastewater disposal options from Waste Generator Services (WGS) and/or the appropriate environmental personnel. Nonroutine releases to the ground surface or to wastewater land application facilities (WLAFs) must be approved by the applicable facility manager prior to disposal. In order to maintain records of these specific releases, the project manager shall submit release information to WGS as required by WGS operating procedures. A Waste Determination and Disposition Form (WDDF) (Form 435.39) will be provided by WGS for this purpose. As required by WGS procedures, release information will be tracked in the WGS Integrated Waste Tracking System (IWTS). Monitoring or production-well purge water releases consisting of groundwater known to be uncontaminated or contaminated below MCLs are exempt from the approval requirements.

A review of the WGS information for Calendar Year 2006 did not identify any records showing wastewater discharges to the soil exceeding MCLs. There were no BAT plans developed by BEA or CWI that were submitted to the DOE Idaho Operations Office (DOE-ID) in 2006.

In addition, effluent radiological data from the Environmental Monitoring Information System (EMIS) and the Environmental Data Warehouse (EDW) for Calendar Year 2006 were reviewed for the following WLAFs:

- $\quad$ Central Facilities Area Sewage Treatment Plant (CFA STP)

- $\quad$ Idaho Nuclear Technology and Engineering Center (INTEC) New Percolation Ponds

- $\quad$ MFC Industrial Waste Ditch (IWD)

- $\quad$ MFC Industrial Waste Pond (IWP)

- $\quad$ Reactor Technology Complex (RTC) Cold Waste Pond (CWP)

- $\quad$ Test Area North/Technical Support Facility (TAN/TSF) Sewage Treatment Facility (STF) Disposal Pond

Table 1 shows the WLAF facility, the radiological analysis performed, and the frequency the effluent samples are collected.

All radioactivity levels ${ }^{\mathrm{b}}$, with the exception of one gross alpha sample result in the effluent to the INTEC New Percolation Ponds and one Radium-226 (Ra-226) sample result taken from the effluent to the RTC CWP were reported as undetected or below MCLs. In addition, the majority of the radionuclides that were analyzed were below the laboratories instrument detection level.

Several monthly samples taken from the INTEC CPP-797 (effluent to the New Percolation Ponds) structure in 2006 contained activity levels for gross alpha above $5 \mathrm{pCi} / \mathrm{L}$. If gross alpha exceeds $5 \mathrm{pCi} / \mathrm{L}$, PLN-932 requires that the sample shall be analyzed for Ra-226 and Ra-228. However, process knowledge may be used to determine whether these analyses should be performed. An evaluation of the radionuclides expected in the wastewater discharged to the New Percolation Ponds has been completed (EDF-4545).

b. Radiological data obtained from the EMIS and EDW. 
The evaluation determined that Ra-226 and Ra-228 were not likely to be present in this waste stream. Therefore, Ra-226 and Ra-228 analyses were not performed.

The October 2006 monthly sample result from a sample collected at INTEC CPP-797 showed a gross alpha activity level of $18.4 \mathrm{pCi} / \mathrm{L}$. PLN-932 requires that the sample should be analyzed for expected specific alpha emitters when the activity level is above $15 \mathrm{pCi} / \mathrm{L}$. However, this sample was J-flagged during the data validation process. The J-flag indicated that the sample result may have been biased high due to the blank result. Because of the J-flag and possible high bias, a decision was made to analyze the sample in triplicate. All three sample results $(5.95 \mathrm{pCi} / \mathrm{L}, 11.9 \mathrm{pCi} / \mathrm{L}$, and $5.92 \mathrm{pCi} / \mathrm{L})$ were below $15 \mathrm{pCi} / \mathrm{L}$. Therefore, no alpha specific analyses were performed. Based on the reanalysis results, it was determined that no MCLs were exceeded.

Environmental surveillance samples are collected quarterly from the effluent that is discharged to the RTC CWP. Ra-226 is both an alpha and gamma emitter and has an MCL of $5 \mathrm{pCi} / \mathrm{L}$. Ra-226 was detected in the November 2006 sample analyzed for gamma at $13 \mathrm{pCi} / \mathrm{L}$. The Ra-226 sample result was J-flagged during data validation. The sample result was qualified "J," indicating the sample result is greater than the 2 sigma (2S) uncertainty but less than 3 times $(3 \mathrm{~S})$ the uncertainty and above the laboratory minimum detectable activity (MDA) of $5.533 \mathrm{pCi} / \mathrm{L}$. Ra-226 was not detected in any of the other quarterly samples collected in 2006 . The gross alpha and all other gamma results for November 2006 were reported as undetected. In addition, duplicate samples collected in January 2007 and analyzed for Ra-226 both had results reported as undetected. 
Table 1. Frequency of sampling and the analyses performed at each WLAF.

\begin{tabular}{|l|c|c|c|c|c|c|}
\hline \multicolumn{1}{|c|}{ Analysis } & CFA STP & $\begin{array}{c}\text { INTEC New } \\
\text { Percolation Ponds }\end{array}$ & MFC IWD & MFC IWP & RTC CWP & TAN/TSF STF \\
\hline Americium-241 & NA & NA & Annually & Annually & NA & NA \\
\hline Curium-243 & NA & NA & Annually & Annually & NA \\
\hline Gross Alpha & Annually & Monthly & Monthly & Monthly & Quarterly & Quarterly \\
\hline Gross Beta & Annually & Monthly & Monthly & Monthly & Quarterly & Quarterly \\
\hline Gamma Spec & Annually & Monthly & Monthly & Monthly & Quarterly & Quarterly \\
\hline Iodine-129 & Annually & NA & NA & NA & Quarterly & NAnually \\
\hline Iron-55 & NA & NA & Annually & Annually & NA & NA \\
\hline Plutonium Isotopes & NA & NA & Annually & Annually & Quarterly & Annually \\
\hline Strontium (Sr)-89/90 & Annually & Monthly & Annually & Annually & Monthly (Sr-90 only) \\
\hline Tritium & Annually & NA & Monthly & Monthly & Quarterly & Annually \\
\hline Uranium Isotopes & NA & NA & Annually & Annually & NA & NA \\
\hline
\end{tabular}

$$
\text { a. NA - Not Analyzed. }
$$




\section{CONCLUSION}

In 2006, BEA used plan PLN-8104 and CWI used PLN-932 during Calendar Year 2006 to determine wastewater disposal paths. Following these plans ensures that wastewater is disposed of in compliance with the DOE Order 5400.5 BAT requirements.

A review of the 2006 WGS waste disposal records did not show any discharges to the soil with radioactivity levels greater than MCLs. In addition, 2006 radiological data from effluent samples collected at the WLAFs was reviewed. The only MCL that was exceeded was Ra-226 $(5 \mathrm{pCi} / \mathrm{L})$ in the November 2006 sample $(13 \mathrm{pCi} / \mathrm{L})$ collected from the effluent to the RTC CWP. No other MCLs were exceeded in samples collected from the effluent to the RTC CWP during 2006. Radiological contaminants are not intentionally discharged to the CWP. Therefore, it is possible that the Ra-226 in the November 2006 sample was a combination of natural background radioactivity and analytical inaccuracies. It was determined from the review that no other MCLs were exceeded in the wastewater discharges to the other WLAFs.

Based on the review of the information discussed in this report, it has been concluded that both BEA and CWI are in compliance with the BAT requirements in DOE Order 5400.5. 


\section{REFERENCES}

DOE O 5400.5, Change 2 "Radiation Protection of the Public and the Environment," U. S. Department of Energy, January 7, 1993.

EDF-4545, "Sample Analysis of the Service Waste System, Monthly Composite Samples," Rev.1, December 21, 2004.

PLN-932, "Management Plan and Implementation of Best Available Technology per DOE Order 5400.5 for Disposal of Wastewater," Rev. 1, June 8, 2006.

PLN-8104, "Management Plan and Implementation of Best Available Technology per DOE Order 5400.5 for Disposal of Wastewater," Rev. 0, July 18, 2006. 